\title{
ANALISIS NILAI TUKAR PETANI KABUPATEN JOMBANG TAHUN 2018
}

\author{
Markus Patiung \\ markuspatiung@uwks.ac.id \\ Dosen Program Studi Agribisnis \\ Fakultas Pertanian \\ Universitas Wijaya Kusuma Surabaya
}

\begin{abstract}
ABSTRAK
Analisis Nilai Tukar Petani (NTP) Kabupaten Jombang Tahun 2018 bertujuan untuk mengetahui tingkat kesejahteraan petani dan fluktuasi harga komoditi pertanian. Metode analisis yang digunakan adalah Analisa Deskriptif, yaitu analisa terhadap data yang bersifat kualitatif dan kuantitatif, baik data primer maupun sekunder. Nilai Tukar Petani (NTP) dihitung dengan rumus nisbah/ratio antara Indeks Harga yang Diterima Petani $\left(\mathrm{It}_{\mathrm{n}}\right)$ dan Indeks Harga yang Dibayar Petani $\left(\mathrm{Ib}_{\mathrm{n}}\right)$.

Hasil pemantauan dan analisis harga-harga pedesaan di 21 kecamatan di kabupaten Jombang pada tahun 2018, NTP kabupaten Jombang naik sebesar 0,07 persen dibandingkan pada tahun 2017, yaitu dari 113,92 menjadi 113,99. Kenaikan NTP pada tahun 2018 disebabkan indeks harga yang diterima petani mengalami kenaikan sebesar 2,0 persen lebih besar dari pada kenaikan indeks harga barang dan jasa yang dikonsumsi oleh rumah tangga maupun untuk keperluan produksi pertanian sebesar 1,70 persen.. Selain itu kenaikan nilai tukar petani kabupaten Jombang juga dipengaruhi oleh kenaikan indeks harga pada masingmasing sub-sektor, yakni subsektor tanaman pangan sebesar 0,04 persen, tanaman hortikultura sebesar 0,05 persen, tanaman perkebunan rakyat naik sebesar 0,02 persen, peternakan naik sebesar 0,13 persen dan subsektor perikanan naik sebear 0,39 persen.
\end{abstract}

Kata Kunci : Petani, Nilai, Tukar, Analisis.

\section{PENDAHULUAN}

\section{Latar Belakang}

Salah satu indikator untuk mengukur tingkat kesejahteraan petani di daerah pedesaan adalah indikator nilai tukar petani (NTP). NTP merupakan perbandingan antara indeks harga yang diterima petani (IT) dengan indeks harga yang dibayar petani (IB). Indeks Harga Yang Diterima Petani (It) adalah indeks yang mencerminkan fluktuasi harga barang-barang yang dihasilkan oleh petani. Indeks ini digunakan juga sebagai data penunjang dalam perhitungan pendapatan sektor pertanian. Sedangkan dari Indeks Harga Yang Dibayar Petani (Ib), dapat digambarkan fluktuasi harga barang-barang yang dikonsumsi oleh rumah tangga petani dan harga barang-barang yang dibutuhkan untuk menghasilkan produk pertanian. Perkembangan angka Indeks Harga Yang Dibayar Petani (Ib) juga dapat menggambarkan perkembangan angka inflasi di pedesaan.

Perhitungan NTP mencakup seluruh jenis komoditi pertanian. Untuk komoditi subsektor tanaman pangan mencakup padi dan palawija. Sub-sektor hortikultura mencakup tanaman sayur-sayuran dan buah-buahan, dan tanaman obat-obatan. Sub-sektor Tanaman Perkebunan Rakyat (TPR) mencakup tanaman tebu, kelapa, kopi robusta, cengkeh dan tembakau. Jumlah dan jenis komoditi ini bervariasi antar daerah. Untuk sub-sektor peternakan mencakup ternak besar (sapi dan kerbau), ternak kecil (kambing, domba, dan 
babi dan lainnya), unggas (ayam, itik dan lainnya), hasil-hasil ternak (susu sapi, telur, dan lainnya). Subsektor perikanan, baik perikanan tangkap maupun perikanan budidaya.

Perkembangan NTP merupakan indikator penting bagi daerah yang bertumpu pada sektor pertanian. Oleh karena itu pemerintah Kabupaten Jombang sebagai salah satu wilayah yang menekankan pembangunan pada sektor pertanian, setiap tahun melaksanakan perhitungan indeks tersebut. Dengan menghitung dan memahami esensi dari NTP, pemerintah Kabupaten Jombang tidak hanya mempertahankan keberadaan sektor pertanian dengan ciri khas tradisionalnya, namun berkomitmen terus menerus melakukan transformasi pertanian ke arah yang lebih maju dan modern. yaitu dengan meningkatkan industrialisasi pertanian (agroindustri) yang diharapkan mampu memberikan nilai tambah terhadap sektor pertanian.

NTP sebagai pendekatan pengukuran kesejahteraan petani hanya memperhitungkan dampak perubahan harga komoditi pada saat ini dengan tahun dasar perhitungannya. Pendekatan ini perlu diperkaya dengan memasukkan unsur peningkatan produksi dan produktivitas komoditi yang terjadi setiap tahunnya di Kabupaten Jombang.

Berdasarkan latar belakang pemikiran tersebut, maka pemerintah Kabupaten Jombang, perlu melaksanakan kegiatan Analisis Nilai Tukar Petani Kabupaten Jombang Tahun 2018. Kegiatan ini merupakan pemantauan perkembangan harga-harga produksi pertanian, dan barang-barang konsumsi pertanian di seluruh kecamatan, yaitu di 21 kecamatan, Kabupaten Jombang.

\section{Rumusan Masalah}

Secara umum kondisi petani di kabupaten Jombang dicirikan dengan tingkat penguasaan lahan yang sempit, tingkat pendidikan yang rendah, keterbatasan permodalan, sulit mengakses teknologi, jumlah tanggungan keluarga yang besar dan lainnya. Selain itu petani juga pada umumnya sangat lemah dalam menentukan harga jual dari produk hasilhasil pertanian mereka. Dan harga-harga sarana produksi dan harga barang konsumsi sangat sulit untuk dikendalikan. Hal ini yang menyebabkan sulitnya petani untuk mewujudkan tingkat kesejahteraan mereka.

Berbagai upaya yang telah dilakukan pemerintah kabupaten Jombang dalam pembangunan pertanian yakni dalam Rencana Pembangunan Jangka Panjang (RPJP) Kabupaten Jombang tahun 2005-2025, telah mengamanatkan dalam misi pembangunannya, yaitu meningkatkan pertumbuhan ekonomi yang berbasis pada sektor pertanian dan produk unggulan daerah. Upaya mewujudkan struktur perekonomian yang berbasis pada sektor pertanian sebagai penggerak utama ditempuh dengan cara : 1) membangun sistem keterkaitan produksi, distribusi dan pelayanan public, 2) pengembangan potensi wilayah baik pada daerah sekitar hutan, persawahan, perikanan dan daerah-daerah sekitar kawasan industry dengan mengembangkan produk unggulan yang spesifik dan kompetitif serta berdampak langsung terhadap percepatan pertumbuhan ekonomi dan penciptaan lapangan kerja, 3) meningkatkan nilai tambah dan produktivitas melalui pengembangan industry yang berdaya saing global serta mampu memberikan layanan yang berkualitas serta 4) membangun inkubator agribisnis dan agroindustry dan mengembangkan kawasan pusatpusat pengembangan terpadu.

Tujuan akhir dari proses pembangunan pertanian ini adalah meningkatnya kesejahteraan petani. Untuk itu setiap tahun pemerintah Kabupaten Jombang lewat Badan Perencanaan Pembangunan Kabupaten Jombang (BAPPEDA) khusunya Bidang Litbang 
mengukur tingkat kesejahteraan petani melalui alat ukur Nilai Tukar Petani (NTP). Oleh karena itu rumusan masalah dari kajian ini adalah sebagai berikut:

1. Bagaimana pengaruh fluktuasi harga komoditi pertanian terhadap kesejahteraan petani?

2. Bagaimana tingkat keberhasilan pembangunan sektor pertanian di Kabupaten Jombang tahun 2018?

\section{Tujuan Analisis}

Tujuan yang ingin dicapai dalam kegiatan Analisis Nilai Tukar Petani Kabupaten Jombang Tahun 2018 adalah:

1. Mengetahui tingkat kesejahteraan petani dan fluktuasi harga komoditi pertanian;

2. Mengetahui tingkat keberhasilan pembangunan sektor pertanian Kabupaten Jombang.

\section{Manfaat Kegiatan}

1. Tersedianya dokumen Laporan Nilai Tukar Petani Kabupaten Jombang Tahun 2018.

2. Tersedianya informasi tentang capaian keberhasilan, dampak dan permasalahan dalam pembangunan pertanian di Kabupaten Jombang.

3. Sebagai bahan pertimbangan dalam perencanaan kebijakan dan menentukan program dan kegiatan di sektor pertanian yang akan datang di Kabupaten Jombang.

\section{Ruang Lingkup Kegiatan}

Ruang lingkup, lokasi, data dan fasilitas penunjang kegiatan ini adalah :

1. Lokasi di seluruh wilayah Kabupaten Jombang, meliputi 21 (dua puluh satu) kecamatan.

2. Penghitungan indeks harga yang diterima petani yang meliputi subsektor Tanaman Pangan, tanaman perkebunan, peternakan dan perikanan Kabupaten Jombang tahun 2018;

3. Penghitungan indeks harga yang dibayar meliputi indeks konsumsi rumah tangga dan indeks biaya produksi dan penambahan barang modal Kabupaten Jombang Tahun 2018.

\section{KAJIAN PUSTAKA \\ Pengertian Nilai Tukar Petani}

Kesejahteraan petani secara ekonomi, dapat dilihat dari tingkat pendapatan dan pengeluarannya. Salah satu indikator yang paling sering digunakan dalam mengukur tingkat kesejahteraan petani adalah menggunakan indeks NIlai Tukar Petani (NTP). Batasan Nilai Tukar Petani (NTP) adalah perbandingan/rasio antara Indeks Harga Yang Diterima Petani (It) dengan Indeks Harga Yang Dibayar Petani. Hubungan NTP dengan tingkat kesejahteraan petani sebagai produsen secara nyata terlihat dari posisi It yang berada pada pembilang (enumerator) NTP. Apabila harga barang/produk pertanian naik, dengan asumsi volume produksi tidak berkurang, maka penerimaan/pendapatan petani dari hasil panennya juga akan bertambah. Perkembangan harga yang ditunjukkan It, merupakan sebuah indikator tingkat kesejahteraan petani produsen dari sisi pendapatan (Rosidi, 2007).

Nilai tukar petani secara langsung menggambarkan daya tukar atau daya beli petani terhadap produk yang dibeli atau dibayar petani, yang mencakup barang konsumsi dan 
input sarana produksi. Secara sederhana, dapat dikatakan semakin tinggi nilai tukar petani, maka daya beli petani semakin baik dan berarti kesejahteraan petani lebih baik. Nilai tukar petani menjadi pilihan satu-satunya indikator penanda tingkat kesejahteraan petani, bagi pengamat hasil pembangunan pertanian (BPS. 2006).

Pengetahuan secara mendalam tentang perilaku nilai tukar petani, dampak pembangunan,dan identifikasi faktor-faktor penentu nilai tukar akan sangat berguna bagi perencanaan kebijakan pembangunan, perbaikan program-programpembangunan, serta alokasi anggaran yang lebih berpihak pada usaha-usaha peningkatan kesejahteraan petani.Secara alamiah NTP mempunyai karakteristik yang cenderung menurun. Hal ini berkaitan dengan karakteristik yang melekat dari komoditi pertanian dan non pertanian, yaitu: (1) Elastisitas pendapatan produk pertanian bersifat inelastik, sementara produk non pertanian cenderung lebih elastik, (2) Perubahan teknologi dengan laju yang berbeda menguntungkan produk manufaktur, dan (3) Perbedaan dalam struktur pasar, dimana struktur pasar dari produk pertanian cenderung kompetitif, sementara struktur pasar produk manufaktur cenderung kurang kompetitif dan mengarah ke pasar monopoli/oligopoli (Rachmat, 2000).

Mengacu pada Analisis NTP yang dilakukan oleh Bappenas dan Japan International Cooperation Agency (JICA), pada tahun 2013, Indeks Harga Yang Diterima Petani disusun oleh unsur-unsur indeks harga subsektor tanaman pangan, hortikultura, perkebunan, peternakan, dan perikanan. Sedangkan Indeks Harga Yang Dibayar Petani disusun dari oleh unsurharga pembelian barang konsumsi rumah tangga dan harga pembelian faktor produksi dan barang modal.

\section{Pengukuran Nilai Tukar Petani (NTP)}

Secara konsepsi NTP mengukur daya tukar dari komoditi pertanian yang dihasilkan petani terhadap produk yang dibeli petani untuk keperluan konsumsi dan keperluan dalam memproduksi usahatani. Nilai tukar petani (NTP) didefinisikan sebagai rasio antara harga yang diterima petani (HT) dengan harga yang dibayar petani (HB) atau NTP = HT/HB. Pengukuran NTP dinyatakan dalam bentuk indeks sebagai berikut:

\section{$I N T P=I T / I B$}

Keterangan:

INTP : Indeks Nilai Tukar Petani

IT : Indeks Harga Yang Diterima Petani

IB : Indeks Harga Yang Dibayar Petani

Indeks tersebut merupakan nilai tertimbang terhadap kuantitas pada tahun dasar tertentu. Pergerakan nilai tukar akan ditentukan oleh penentuan tahun dasar karena perbedaan tahun dasar akan menghasilkan keragaan perkembangan indeks yang berbeda. Formulasi indeks yang digunakan adalah Indeks Laspeyres, sebagai berikut:

$$
I=\frac{\sum Q_{0} * P_{i}}{\sum Q_{0} * P_{0}}
$$


Keterangan:

I : Indeks Laspeyres

Qo : Kuantitas pada tahun dasar tertentu (tahun 0)

Po : Harga pada tahun dasar tertentu (tahun 0 )

$\mathrm{Pi} \quad$ : Harga pada tahun ke i

Dalam operasionalisasi penghitungan NTP, BPS memodifikasi Indeks Laspeyres sebagai berikut:

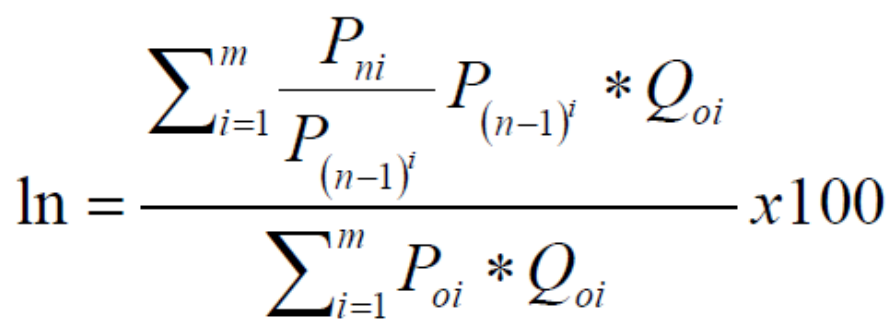

Keterangan:

In $\quad$ : Indeks harga bulanan bulan ke $\mathrm{n}$ (IT dan IB)

Pni : Harga bulan ke $\mathrm{n}$ untuk jenis barang ke $\mathrm{i}$

$\mathrm{P}(\mathrm{n}-1)^{\mathrm{i}} \quad$ : Harga bulan ke (n-1) untuk jenis barang ke $\mathrm{i}$

$\mathrm{Pni} / \mathrm{P}(\mathrm{n}-1)^{\mathrm{i}} \quad$ : Relatif harga bulan ke $\mathrm{n}$ untuk jenis barang ke $\mathrm{i}$

Poi : Harga dasar tahun dasar untuk jenis barang ke $\mathrm{i}$

Qoi : Kuantitas pada tahun dasar untuk jenis barang ke i,

M :Banyaknya jenis barang yang tercakup dalam paket komoditi

Beberapa istilah yang digunakan dalam perhitungan NTP diuraikan sebagai berikut :

\section{Harga yang Diterima Petani (HT)}

Harga yang diterima petani merupakan harga tertimbang dari harga setiap komoditi pertanian yang diproduksi/dijual petani. Penimbang yang digunakan adalah nilai produksi yang dijual petani dari setiap komoditi. Harga komoditi pertanian merupakan harga rataan yang diterima di tingkat petani atau "Farm Gate". Petani yang dimaksud dalam konsep NTP dari Badan Pusat Statistik adalah petani yang berusaha di subsektor tanaman pangan, hortikultura, perkebunan rakyat, peternak, serta petani ikan budidaya dan nelayan. Petani sub sektor tanaman pangan mencakup petani yang berusaha pada usahatani padi dan palawija; petani subsektor hortikultura mencakup petani sayur-sayuran dan buah-buahan; petani perkebunan rakyat terdiri usahatani komoditi perdagangan rakyat; petani peternak yang bergerak dalam usaha ternak besar, ternak kecil, unggas, dan hasil peternakan; serta petani nelayan yang mencakup petani budidaya ikan dan nelayan penangkapan.

\section{Harga yang Dibayar Petani (HB)}

Harga yang dibayar petani merupakan harga tertimbang dari harga/biaya konsumsi makanan, konsumsi non makanan dan biaya produksi dan penambahan barang modal dari barang yang dikonsumsi atau dibeli petani. Komoditi yang dihasilkan sendiri tidak masuk dalam perhitungan harga yang dibayar petani. Harga yang dimaksud adalah harga eceran barang dan jasa yang dipasar pedesaan.

Secara konsepsi arah dari NTP (kesejahteraan petani) merupakan resultan dari arah setiap Nilai Tukar Komponen Pembentuknya, yaitu nilai tukar komponen penerimaan 
petani yang mempunyai arah positif terhadap kesejahteraan petani dan nilai tukar komponen pembayaran yang mempunyai arah negatif terhadap kesejahteraan petani. Apabila laju nilai tukar komponen penerimaan lebih tinggi dari laju nilai tukar komponen maka Nilai Tukar Petani (NTP) akan meningkat, demikian sebaliknya.

Perhitungan NTP merupakan merupakan agregasi dari nilai tukar penyusunnya. NTP merupakan agregasi dari NTP sub sektor (yaitu sub sektor tanaman pangan, sub sektor hortikultura, sub sektor perkebunan, sub sektor peternakan,dan sub sektor perikanan). NTP sub sektor tanaman pangan disusun dari komponen NTP padi dan NTP kelompok palawija,dan NTP palawija disusun dari NTP komoditi palawija (jagung, kedelai, dan sebagainya). BPS mendefinisikan dan memberi arti NTP sebagai berikut:

a. NTP > 100, berarti petani mengalami surplus.

Harga produksinya naik lebih besar dari kenaikan harga konsumsi dan biaya produksi. Pendapatan petani naik lebih besar dari pengeluarannya, dengan demikian tingkat kesejahteraan petani lebih baik dibanding tingkat kesejahteraan petani sebelumnya.

b. $\quad \mathrm{NTP}=100$, berarti petani mengalami impas/break even.

Kenaikan/penurunan harga produksi sama dengan persentase kenaikan/ penurunan harga konsumsi dan biaya produksi. Tingkat kesejahteraan petani tidak mengalami perubahan.

c. NTP $<100$, berarti petani mengalami defisit. Harga produksinya naik lebih kecil dari kenaikan harga konsumsi dan biaya produksi. Tingkat kesejahteraan petani mengalami penurunan dibanding tingkat kesejahteraan petani sebelumnya.

\section{METODE PENELITIAN}

\section{Metode Penentuan Lokasi dan Sasaran}

Lokasi kegiatan Analisis Nilai Tukar Petani Kabupaten Jombang tahun 2018 dilakukan di wilayah administrasi Pemerintah Kabupaten Jombang, yaitu di 21 kecamatan. Sasaran dari kegiatan ini adalah para petani Kabupaten Jombang yang terbagi dalam 5 (lima) subsektor, yaitu tanaman pangan, tanaman hortikultura, tanaman perkebunan rakyat, peternakan dan perikanan.

\section{Metode Penentuan Sampel Responden}

Dalam menentukan ukuran sampel, harus diketahui jumlah populasi data (N) wilayah penelitian, dan menetapkan taraf signifikansi $(\alpha)$ yang diinginkan. Ada 2 metode praktis, yaitu menggunakan Tabel Kretjie, dan Rumus Slovin. Populasi data dalam kajian ini adalah rumah tangga petani secara keseluruhan pada 21 kecamatan di Kabupaten Jombang berdasarkan data Sensus Pertanian Tahun 2013, yaitu sebesar 124.562 unit rumah tangga petani (RTP). Berdasarkan Tabel Kretjie, jumlah sampel responden minimal pada taraf siginikansi 5\% untuk Kabupaten Jombang adalah sebesar 347 RTP. Sedangkan berdasarkan rumus Slovin menghasilkan jumlah sampel minimal pada taraf signifikansi 5\% adalah sebesar 399 RTP.

Sampel responden dipilih melalui Non-probability Sampling yaitu teknik yang tidak memberi peluang yang sama bagi setiap anggota populasi untuk dipilih menjadi sampel. Teknik pengambilan sampel dilakukan dengan metode purposive sampling yaitu pengembilan sampel dengan mengutamakan pertimbangan karakteristik tertentu. Pertimbangannya adalah luas komoditi pertanian dan jumlah petani di setiap kecamatan. 
Berdasarkan metode perhitungan sampel minimal tersebut diatas maka kajian ini menetapkan jumlah sampel rumah tangga petani keseluruhan sebanyak 420 petani, atau rata-rata 20 petani dari setiap kecamatan, yang mewakili 5 subsektor tersebut diatas secara proporsional berdasarkan luas lahan eksisting dari setiap subsektor. Jumlah sampel tersebut telah melebihi jumlah sampel minimal yang dibutuhkan dengan taraf signifikansi 0.05 atau tingkat kesalahan data sebesar maksimal 5\%. Perhitungan penentuan jumlah sampel selengkapnya diuraikan dalam lampiran laporan ini.

\section{Metode Pengumpulan Data}

Data yang akan digunakan dalam analisaini berupa data kualitatif dan data kuantitatif. Kedua jenis data tersebut berasal dari data primer dan data sekunder. Data primer diperoleh melalui metode wawancara terstruktur menggunakan alat bantu kuesioner. Sedangkan data sekunder, diperoleh melalui metode studi pustaka, konsultasi data pertanian, data harga komoditi dan data penunjang lainnya dengan SKPD terkait dalam kajian ini.

\section{Metode Analisis}

Metode analisis yang digunakan adalah Analisa Deskriptif, yaitu analisa terhadap data yang bersifat kualitatif dan kuantitatif, baik data primer maupun sekunder. Hasil analisis berupa deskripsi yang mampu memberikan pemecahan masalah dan mencapai tujuan dari kegiatan. Adapun alat bantu yang digunakan untuk melakukan analisis adalah metode perhitungan Nilai Tukar Petani, Analisis Usahatani dan Struktur Pengeluaran Rumah Tangga Petani. Uraian masing-masing alat analisis tersebut sebagai berikut :

\section{Nilai Tukar Petani}

Nilai Tukar Petani (NTP) dihitung dengan rumus nisbah/ratio antara Indeks Harga yang Diterima Petani $\left(\mathrm{It}_{\mathrm{n}}\right)$ dan Indeks Harga yang Dibayar Petani $\left(\mathrm{Ib}_{\mathrm{n}}\right)$, sebagai berikut :

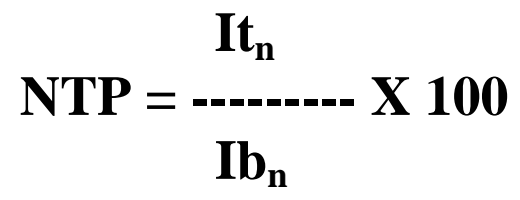

Keterangan:

NTP $=$ Nilai Tukar Petani

$\mathrm{It}_{\mathrm{n}} \quad=$ Indeks Harga yang Diterima Petani tahun ke-n

$\mathrm{Ib}_{\mathrm{n}} \quad=$ Indeks Harga yang Dibayar Petani tahun ke-n

Perilaku Nilai Tukar Petani dapat menjelaskan factor-faktor apa saja yang mempengaruhi perubahan atau pergerakan nilai tukar tersebut. Untuk mengetahui penyebab perubahan tersebut, dilakukan dekomposisi terhadap komponen pembentuk NTP. Dekomposisi tersebut dilakukan berdasarkan komoditi dan berdasarkan kelompok/ jenis pengeluaran petani.

1. NTP berdasarkan kelompok komiditi akan menghasilkan indeks:

a. NTP Tanaman Pangan;

b. NTP Tanaman Hortikultura;

c. NTP Tanaman Perkebunan;

d. NTP Peternakan;

e. NTP Perikanan.

2. NTP berdasarkan kelompok pengeluaran petani menghasilkan indeks:

a. NTP Terhadap Konsumsi Makanan Minuman (Mamin); 
b. NTP Terhadap Konsumsi Non Makanan;

c. NTP Terhadap Penambahan Barang Modal;

\section{HASIL DAN PEMBAHASAN}

\section{Nilai Tukar Petani (NTP) Kabupaten Jombang}

Berdasarkan hasil pemantauan dan analisis harga-harga pedesaan di 21 kecamatan di kabupaten Jombang pada tahun 2018, NTP kabupaten Jombang naik sebesar 0,07 persen dibandingkan pada tahun 2017, yaitu dari 113,92 menjadi 113,99. Kenaikan NTP pada tahun 2018 disebabkan indeks harga hasil produksi pertanian atau indeks harga yang diterima petani mengalami kenaikan lebih besar dari pada kenaikan indeks harga barang dan jasa yang dikonsumsi oleh rumah tangga maupun untuk keperluan produksi pertanian. Selain itu kenaikan nilai tukar petani kabupaten Jombang juga dipengaruhi oleh kenaikan indeks harga pada masing-masing sub-sektor.

Adapun nilai tukar petani, indeks harga yang diterima petani serta indeks harga yang dibayar petani kabupaten Jombang dapat dilihat secara rinci pada tabel 1.

\section{Tabel 1}

Nilai Tukar Petani, Indeks Harga Yang Diterima Petani dan Indeks Harga Yang Dibayar Petani

Serta Persentase Perubahannya $(2012=100)$

\begin{tabular}{|c|c|c|c|c|}
\hline \multirow[t]{2}{*}{ No } & \multirow[t]{2}{*}{ Uraian } & \multicolumn{2}{|c|}{ Tahun } & \multirow[t]{2}{*}{ Perubahan $(\%)$} \\
\hline & & 2017 & 2018 & \\
\hline \multicolumn{5}{|c|}{ Gabungan/Kabupaten } \\
\hline 1 & Nilai Tukar Petani (NTP) & 113,92 & 113,99 & 0,07 \\
\hline 2 & Indeks Harga Yang Diterima Petani (It) & 117,91 & 119,91 & 2,00 \\
\hline 3 & Indeks Harga Yang Dibayar Petani (Ib) & 103,50 & 105,20 & 1,70 \\
\hline & a. Konsumsi Rumah Tangga & 104,78 & 106,94 & 2,16 \\
\hline & $\begin{array}{l}\text { b. Biaya Produksi dan Penambahan Barang Modal } \\
\text { (BPPBM) }\end{array}$ & 103,20 & 104,60 & 1,40 \\
\hline
\end{tabular}

\section{Indeks Harga Yang Diterima Petani (It)}

Sumber : Analisis Data Primer

Pada Tahun 2018 indeks harga yang diterima petani (It) naik sebesar 2,00 persen dibanding pada tahun 2017, yakni dari 117,91 menjadi 119,91. Kenaikan indeks harga yang diterima petani (It) pada tahun 2018 disebabkan naiknya indeks harga pada sub-sektor tanaman pangan sebesar 0,04 persen, sub-sektor tanaman hortikultura sebesar 0,05 persen, sub-sektor tanaman perkebunan rakyat sebesar 0,02 persen, sub-sektor peternakan naik sebesar 0,13 persen, perikanan naik sebesar 0,39 persen.

Adapun data kenaikan indeks harga di masing-masing sub-sektor dapat dilihat secara rinci pada tabel 2. 
Tabel 2

Nilai Tukar Petani Per Sub-Sektor

Serta Persentase Perubahannya $(2012=100)$

\begin{tabular}{|c|l|c|c|c|}
\hline \multirow{2}{*}{ No } & Sub-Sektor & \multicolumn{2}{|c|}{ NTP } & \multirow{2}{*}{ Kenaikan (\%) } \\
\cline { 3 - 5 } & & 2017 & 2018 & \\
\hline Gabungan/Kabupaten & & & \\
\hline 1 & Tanaman Pangan & 115,22 & 115,26 & 0,04 \\
\hline 2 & Tanaman Hortikultura & 113,18 & 113,23 & 0,05 \\
\hline 3 & Tanaman Perkebunan Rakyat & 114,02 & 114,75 & 0,02 \\
\hline 4 & Peternakan & 112,48 & 112,15 & 0,13 \\
\hline 5 & Perikanan & \multicolumn{3}{c|}{ Sumber : Analisis Data Primer } \\
\hline
\end{tabular}

\section{Indeks Harga Yang Dibayar Petani (Ib)}

Melalui indeks harga yang dibayar petani (Ib) dapat dilihat fluktuasi harga barang dan jasa yang dikonsumsi oleh masyarakat pedesaan, khususnya petani yang merupakan bagian terbesar dari masyarakat pedesaan, serta fluktuasi barang dan jasa yang diperlukan untuk memproduksi hasil pertanian.

Pada tahun 2018 secara umum indeks harga yang dibayar petani (Ib) naik sebesar 1,70 persen dibanding Indeks harga yang dibayar petani pada tahun 2017, yaitu dari 103,50 menjadi 105,20 pada tahun 2018. Kenaikan indeks harga yang dibayar petani (Ib) tersebut disebabkan kenaikan indeks harga pada konsumsi rumah tangga sebesar 2,16 persen dan biaya produksi dan penambahan barang modal sebesar 1,40 persen.

\section{Nilai Tukar Petani Menurut Sub-Sektor.}

\section{Nilai Tukar Petani (NTP) Tanaman Pangan.}

Pada tahun 2018 terjadi kenaikan nilai tukar petani pada sub-sektor tanaman pangan bila dibandingkan pada tahun 2017, yakni sebesar 0,04 persen. Hal ini terjadi karena baik indeks harga yang diterima petani (It) dan Indeks harga yang dibayar petani (Ib) sama-sama mengalai kenaikan. Indeks harga yang diterima petani (It) naik sebesar 2,83 persen sedangkan indeks harga yang dibayar petani (Ib) naik sebesar 2,41 persen.

Tabel 3.

Nilai Tukar Petani, Indeks Harga Yang Diterima Petani, Dan Indeks Harga Yang Dibayar Petani pada

Sub Sektor Tanaman Pangan.

\begin{tabular}{|c|c|c|c|c|}
\hline \multirow{2}{*}{ No. } & \multirow{2}{*}{ Uraian } & \multicolumn{2}{|c|}{ NTP } & \multirow{2}{*}{$\begin{array}{c}\text { Kenaikan } \\
(\%)\end{array}$} \\
\hline & & 2017 & 2018 & \\
\hline & Nilai Tukar Petani (NTP) & 115.22 & 115.26 & 0.04 \\
\hline \multirow[t]{3}{*}{1} & Indeks Harga Yang Diterima Petani (It) & 117.59 & 120.45 & 2.86 \\
\hline & a. Jagung & 120.12 & 122.23 & 2.11 \\
\hline & b. Palawija & 114.32 & 116.49 & 2.17 \\
\hline 2 & Indeks Harga Yang Dibayar Petani (Ib) & 102.06 & 104.51 & 2.45 \\
\hline \multirow[t]{9}{*}{2.1} & Konsumsi Rumah Tangga & 104.00 & 105.78 & 1.78 \\
\hline & a. Bahan Makanan dan Minuman & 105.36 & 107.13 & 1.77 \\
\hline & Makanan Jadi & 112.87 & 114.24 & 1.37 \\
\hline & b. Non Makanan & 102.52 & 103.76 & 1.24 \\
\hline & Perumahan & 103.38 & 105.37 & 1.99 \\
\hline & Sandang & 103.43 & 104.48 & 1.05 \\
\hline & Kesehatan & 110.82 & 111.08 & 0.26 \\
\hline & Pendidikan, Rekreasi \& Olah raga & 100.03 & 100.58 & 0.55 \\
\hline & Transportasi \& Komunikasi & 99.86 & 101.44 & 1.58 \\
\hline
\end{tabular}




\begin{tabular}{|l|l|c|c|c|}
\hline \multirow{2}{*}{ No. Uraian } & \multicolumn{2}{|c|}{ NTP } & \multirow{2}{*}{$\begin{array}{c}\text { Kenaikan } \\
(\boldsymbol{\%})\end{array}$} \\
\cline { 3 - 4 } 2.2. & BPPBM & $\mathbf{2 0 1 7}$ & $\mathbf{2 0 1 8}$ & 0.87 \\
\hline & Bibit & 101.84 & 102.71 & 1.30 \\
\hline & Pupuk dan Pestisida & 102.25 & 103.55 & 0.55 \\
\hline & Sewa Tenaga dan Hewan & 102.17 & 102.72 & 0.21 \\
\hline & Upah Buruh & 101.28 & 101.49 & 1.35 \\
\hline & Pengeluaran Lain & 102.70 & 104.05 & 1.13 \\
\hline & Barang Modal & 100.59 & 101.72 & 0.08 \\
\hline
\end{tabular}

Sumber data : Analisis Data Primer

Kenaikan indeks harga yang diterima petani (It) pada tahun 2018 sebesar 2,86 persen dibanding dengan tahun 2017, hal ini disebabkan karena indeks harga kelompok jagung naik sebesar 2,11 persen, dan indeks harga kelompok palawija naik sebesar 2,17 persen. Kenaikan indeks harga yang dibayar petani (Ib) tanaman pangan pada tahun 2018 sebesar 2,45 persen dibanding dengan tahun 2017, hal ini disebabkan kenaikan indeks harga pada kelompok konsumsi rumah tangga sebesar 1,78 persen dan kelompok Biaya Produksi dan Penambahan Barang Modal sebesar 0,87 persen.

Kenaikan indeks harga pada kelompok konsusmsi rumah tangga sebesar 1,78 persen disebabkan kenaikan indek harga pada bahan makanan dan minuman sebesar 1,77 persen, indeks harga makanan jadi naik sebesar 1,37 persen, serta non makanan sebesar 1,24 persen.

Kenaikan indeks harga pada kempok non makanan sebesar 1,24 persen, perumahan sebesar 1,99 persen, sandang naik sebesar 1,05 persen, kesehatan naik sebesar 0,26 persen, pendidikan rekreasi dan olah raga sebesar 0,55 persen serta transportasi dan komunikasi sebesar 1,58 persen.

Kenaikan indeks harga pada kelompok biaya produksi dan penambahan barang modal sebesar 0,87 persen, disebabkan karena kenaikan indeks harga pada bibit sebesar 1,30 persen, pupuk dan pestisida sebesar 0,55 persen, sewa tenaga dan hewan sebesar 0,21 persen, upah buruh sebesar 1,35 persen, pengeluaran lain sebesar 1,13 persen dan barang modal sebesar 0,08 persen.

\section{Nilai Tukar Petani (NTP) Tanaman Hortikultura}

Pada tahun 2018 terjadi kenaikan nilai tukar petani pada tanaman hortikultura sebesar 0,05 persen dibanding pada tahun 2017, yakni sebesar 113,18 pada tahun 2017 menjadi 113,23 pada tahun 2018. Hal ini terjadi karena kenaikan indeks harga yang diterima petani (It) sebesar 1,03 persen, dan Indeks harga yang dibayar petani (Ib) naik sebesar 0,86 persen.

Tabel 4

Nilai Tukar Petani, Indeks Harga Yang Diterima Petani, Indeks Harga Yang Dibayar Petani pada

Sub Sektor Tanaman Hortikultura

\begin{tabular}{|c|l|c|c|c|}
\hline \multirow{2}{*}{ No. Uraian } & \multicolumn{2}{|c|}{ NTP } & \multirow{2}{*}{$\begin{array}{c}\text { Kenaikan } \\
\text { (\%) }\end{array}$} \\
\cline { 3 - 5 } & & $\mathbf{2 0 1 7}$ & $\mathbf{2 0 1 8}$ & \\
\hline & Nilai Tukar Petani (NTP) & 113.18 & $\mathbf{1 1 3 . 2 3}$ & 0.05 \\
\hline $\mathbf{1}$ & Indeks Harga Yang Diterima Petani (It) & 117.01 & 118.04 & 1.03 \\
\hline & a. Sayur-sayuran & 118.12 & 119.03 & 0.91 \\
\hline & b. Buah-buahan & 115.23 & 116.14 & 0.91 \\
\hline & c. Tanaman Obat & 105.64 & 107.65 & 2.01 \\
\hline
\end{tabular}




\begin{tabular}{|c|l|c|c|c|}
\hline \multirow{2}{*}{ No. Uraian } & \multicolumn{2}{|c|}{ NTP } & \multirow{2}{*}{$\begin{array}{c}\text { Kenaikan } \\
(\boldsymbol{\%})\end{array}$} \\
\cline { 3 - 5 } & & $\mathbf{2 0 1 7}$ & $\mathbf{2 0 1 8}$ & \\
\hline $\mathbf{2}$ & Indeks Harga Yang Dibayar Petani (Ib) & 103.39 & 104.25 & 0.86 \\
\hline $\mathbf{2 . 1}$ & Konsumsi Rumah Tangga & 104.01 & 104.29 & 0.28 \\
\hline & a. Bahan Makanan dan Minuman & 103.10 & 104.38 & 1.28 \\
\hline & Makanan Jadi & 109.99 & 110.02 & 0.03 \\
\hline & b. Non Makanan & 103.31 & 103.54 & 0.23 \\
\hline & Perumahan & 101.49 & 101.95 & 0.46 \\
\hline & Sandang & 105.41 & 105.81 & 0.40 \\
\hline & Kesehatan & 102.90 & 103.56 & 0.66 \\
\hline & Pendidikan, Rekreasi \& Olah raga & 103.75 & 104.89 & 1.14 \\
\hline & Transportasi \& Komunikasi & 100.12 & 100.16 & 0.04 \\
\hline $\mathbf{2 . 2 .}$ & BPPBM & 103.24 & 104.23 & 0.99 \\
\hline & Bibit & 103.92 & 104.49 & 0.57 \\
\hline & Pupuk dan Pestisida & 104.46 & 104.69 & 0.23 \\
\hline & Sewa Tenaga dan Hewan & 103.25 & 103.41 & 0.16 \\
\hline & Upah Buruh & 103.50 & 104.88 & 1.38 \\
\hline & Pengeluaran Lain & 102.05 & 103.43 & 1.38 \\
\hline & Barang Modal & 101.78 & 103.00 & 1.22 \\
\hline
\end{tabular}

Indeks harga yang diterima petani sebesar 1,03 persen dari tahun 2017 ke tahun 2018 disebabkan karena kenaikan indeks harga pada kelompok sayur-sayuran sebesar 0,91 persen dan buah-buahan sebesar 0,91 persen, serta tanaman obat-obatan sebesar 2,01 persen.

Indeks harga yang dibayar petani naik sebesar 0,86 persen pada tahun 2018 dibanding dengan tahun 2017, yakni dari 103,39 menjadi 104,25 pada tahun 2018. Hal ini disebabkan karena kenaikan harga pada konsumsi rumah tangga sebesar 0,28 persen yakni dari 104,01 pada tahun 2017 menjadi 104,29 pada tahun 2018, dan kenaikan biaya produksi dan penambahan barang modal sebesar 0,99 persen yakni dari 103,24 pada tahun 2017 menjadi 104,23 pada tahun 2018.

Indeks harga konsumsi rumah tangga naik sebesar 0,28 persen yakni dari 104,01 pada tahun 2017 menjadi 104,29 pada tahun 2018, hal ini disebabkan kenaikan indeks harga pada bahan makanan dan minuman sebesar 1,28 persen dan kenaikan indeks harga makanan jadi sebesar 0,03 persen serta kenaikan indeks harga non makanan sebesar 0,23 persen.

Indeks harga non makanan naik sebesar 0,23 persen yakni dari 103,31 menjadi 103,54. Hal ini disebabkan karena kenaikan indeks harga pada perumahan sebesar 0,46 persen, sandang sebesar 0,40 persen, kesehatan sebesar 0,66 persen, pendidikan rekreasi dan olah raga sebesar 1,14 persen serta transportasi dan komunikasi sebesar 0,04 persen.

Kenaikan indeks harga pada biaya produksi dan penambahan barang modal sebesar 0,99 persen dari 103,24 pada tahun 2017 menjadi 104,23 pada tahun 2018. Kenaikan indeks harga tersebut disebabkan karena kenaikan indeks harga pada bibit sebesar 0,57 persen, pupuk dan pestisida sebesar 0,23 persen, sewa tenaga dan hewan sebesar 0,16 persen, upah buruh naik sebesar 1,38 persen, pengeluaran lain sebesar naik sebesar 1,38 persen, serta barang modal naik sebesar 1,22 persen. 


\section{Nilai Tukar Petani (NTP) Tanaman Perkebunan Rakyat}

Pada tahun 2018 terjadi kenaikan nilai tukar petani pada sub-sektor tanaman perkebunan rakyat bila dibandingkan pada tahun 2017, yakni sebesar 0,02 persen dari 114,37 pada tahun 2017 menjadi 114,75 pada tahun 2018. Hal ini terjadi karena baik indeks harga yang diterima petani (It) dan Indeks harga yang dibayar petani (Ib) sama-sama mengalai kenaikan. Indeks harga yang diterima petani (It) naik sebesar 0,86 persen sedangkan indeks harga yang dibayar petani (Ib) nak sebesar 0,98 persen.

\section{Tabel 5}

Nilai Tukar Petani, Indeks Harga Yang Diterima Petani, Indeks Harga Yang Dibayar Petani pada Sub Sektor Tanaman Perkebunan Rakyat

\begin{tabular}{|c|l|c|c|c|}
\hline \multirow{2}{*}{ No. Uraian } & \multicolumn{2}{|c|}{ NTP } & \multirow{2}{*}{$\begin{array}{c}\text { Kenaikan } \\
(\%)\end{array}$} \\
\cline { 3 - 4 } & Nilai Tukar Petani (NTP) & $\mathbf{2 0 1 7}$ & $\mathbf{2 0 1 8}$ & 0.02 \\
\hline \multirow{2}{*}{$\mathbf{1}$} & $\begin{array}{l}\text { Indeks Harga Yang Diterima Petani } \\
\text { (It) }\end{array}$ & 114.73 & $\mathbf{1 1 4 . 7 5}$ & 0.86 \\
\hline & Tanaman Perkebunan & 119.48 & 120.34 & 0.34 \\
\hline $\mathbf{2}$ & $\begin{array}{l}\text { Indeks Harga Yang Dibayar Petani } \\
\text { (Ib) }\end{array}$ & 103.90 & 104.88 & 0.98 \\
\hline $\mathbf{2 . 1}$ & Konsumsi Rumah Tangga & 107.84 & 108.77 & 0.93 \\
\hline & a.Bahan Makanan dan Minuman & 109.48 & 109.52 & 0.04 \\
\hline & Makanan Jadi & 103.16 & 103.32 & 0.16 \\
\hline & b. Non Makanan & 108.87 & 108.88 & 0.01 \\
\hline & Perumahan & 112.36 & 115.48 & 3.12 \\
\hline & Sandang & 108.05 & 111.34 & 3.29 \\
\hline & Kesehatan & 102.95 & 108.34 & 5.39 \\
\hline & Pendidikan, Rekreasi \& Olah raga & 105.21 & 110.13 & 4.92 \\
\hline & Transportasi \& Komunikasi & 101.75 & 103.12 & 1.37 \\
\hline $\mathbf{2 . 2 .}$ & BPPBM & 102.73 & 103.73 & 1.00 \\
\hline & Bibit & 103.51 & 104.36 & 0.85 \\
\hline & Pupuk dan Pestisida & 102.94 & 104.80 & 1.86 \\
\hline & Sewa Tenaga dan Hewan & 101.13 & 103.12 & 1.99 \\
\hline & Upah Buruh & 103.42 & 103.46 & 0.04 \\
\hline & Pengeluaran Lain & 101.23 & 101.44 & 0.21 \\
\hline & Barang Modal & 99.77 & 100.51 & 0.74 \\
\hline
\end{tabular}

Sumber data : Analisis Data Primer

Kenaikan indeks harga yang diterima petani (It) pada tahun 2018 dibanding dengan tahun 2017 sebesar 0,86 persen disebabkan karena indeks harga kelompok tanaman perkebunan naik sebesar 0,86 persen.

Kenaikan indeks harga yang dibayar petani (Ib) tanaman perkebunan rakyat pada tahun 2018 dibanding dengan tahun 2017 sebesar 0,98 persen, hal ini disebabkan kenaikan indeks harga pada kelompok konsumsi rumah tangga sebesar 0,93 peren dan kelompok biaya produksi dn penambahan barang modal sebesar 1,00 persen.

Kenaikan indeks harga kelompok konsumsi rumah tanga sebesar 0,93 persen disebabkan kenaikan indeks harga pada bahan makanan dan minuman sebesar 0,04 persen, makanan jadi sebesar 0,16 persen dan non makanan sebesar 0,01 persen.

Kenaikan indeks harga pada kelompok non makanan sebesar 0,01 persen disebabkan karena kenaikan indeks harga pada kelompok perumahan sebesar 3,12 persen, 
sandang sebesar 3,29 persen, kesehatan sebesar 5,39 persen, pendidikan rekreasi dn olh raga sebesar 4,92 persen, srta transportasi dan komunikasi sebesar 1,37 persen.

Kenaikan indeks harga yang pada kelompok biaya produksi dan penambahan barang modal sebesar 1,00 persen dari 102,73 pada tahun 2017 menjadi 103,73 pada tahun 2018, hal ini disebabkan karena kenaikan indeks harga pada bibit sebsar 0,85 persen, pupuk dan pestisida sebesar 1,86 persen, sewa tenaga dan hewan sebesar 1,99 persen, upah buruh sebesar 0,04 persen, pengeluaran lain sebesar 0,21 persen, serta barang modal sebesar 0,74 persen.

\section{Nilai Tukar Petani (NTP) Sub-Sektor Peternakan}

Pada tahun 2018 terjadi kenaikan nilai tukar petani pada sub-sektor peternakan bila dibandingkan pada tahun 2017, yakni sebesar 0,13 persen. Hal ini disebabkan karena kenaikan indeks harga yang diterima petani sebesar 1,01 persen dan kenaikan indeks harga yang dibayar petani sebesar 0,76 persen.

Kenaikan indeks harga yang diterima petani sebesar 1,01 persen disebabkan kenaikan indeks harga pada komoditi ternak besar sebesar 0,09 persen, ternak kecil sebesar 0,62 persen, serta unggas sebesar 0,25 persen.

Tabel 6

Nilai Tukar Petani, Indeks Harga Yang Diterima Petani, Indeks Harga Yang Dibayar Petani pada

Sub Sektor Peternakan

\begin{tabular}{|c|l|c|c|c|}
\hline \multirow{2}{*}{ No. Uraian } & \multirow{2}{*}{ NTP } & \multirow{2}{*}{$\begin{array}{c}\text { Kenaikan } \\
(\boldsymbol{\%})\end{array}$} \\
\cline { 3 - 4 } & & $\mathbf{2 0 1 7}$ & $\mathbf{2 0 1 8}$ & \\
\hline & Nilai Tukar Petani (NTP) & 114.02 & 114.15 & 0.13 \\
\hline $\mathbf{1}$ & Indeks Harga Yang Diterima Petani (It) & 119.46 & 120.47 & 1.01 \\
\hline & Ternak Besar & 119.89 & 119.98 & 0.09 \\
\hline & Ternak Kecil & 120.57 & 121.19 & 0.62 \\
\hline & Unggas & 119.44 & 119.69 & 0.25 \\
\hline $\mathbf{2}$ & Indeks Harga Yang Dibayar Petani (Ib) & 104.77 & 105.53 & 0.76 \\
\hline $\mathbf{2 . 1}$ & Konsumsi Rumah Tangga & 103.81 & 104.57 & 0.76 \\
\hline & a. Bahan Makanan dan Minuman & 105.51 & 107.43 & 1.92 \\
\hline & Makanan Jadi & 104.46 & 104.92 & 0.46 \\
\hline & b. Non Makanan & 103.39 & 104.08 & 0.69 \\
\hline & Perumahan & 103.39 & 104.59 & 1.20 \\
\hline & Sandang & 104.43 & 105.51 & 1.08 \\
\hline & Kesehatan & 102.76 & 103.17 & 0.41 \\
\hline & Pendidikan, Rekreasi \& Olah raga & 102.89 & 103.22 & 0.33 \\
\hline & Transportasi \& Komunikasi & 102.99 & 103.51 & 0.52 \\
\hline $\mathbf{2}$ & BPPBM & 105.26 & 105.71 & 0.45 \\
\hline & Bibit & 104.21 & 106.86 & 2.65 \\
\hline & Vaksin dan Serum & 100.31 & 100.45 & 0.14 \\
\hline & Makanan Ternak & 109.23 & 110.18 & 0.95 \\
\hline & Upah Buruh & 102.55 & 103.46 & 0.91 \\
\hline & Pengeluaran Lain & 110.01 & 110.30 & 0.29 \\
\hline & Barang Modal & 111.35 & 111.36 & 0.01 \\
\hline & \multicolumn{3}{|c|}{ Sumber data : Analisis Data Primer } \\
\hline
\end{tabular}

Kenaikan indeks harga yang dibayar petani (Ib) sub-sektor peternakan pada tahun 2018 dibanding dengan tahun 2017 sebesar 0,76 persen, hal ini disebabkan kenaikan indeks 
harga pada kelompok konsumsi rumah tangga sebesar 0,76 persen. Sedangkan Biaya Produksi dan Penambahan Barang Modal naik sebesar 0,45 persen.

Kenaikan indeks harga pada kelompok konsumsi rumah tangga sebesar 0,76 persen disebabkan karena kenaikan indeks harga pada bahan makanan dan minuman sebesar 1,92 persen, makanan jadi sebesar 0,46 persen dan non makanan sebesar 0,69 persen.

Kenaikan indeks harga pada kelompok non makanan sebesar 0,69 persen disebabkan karena kenaikan indeks harga pada perumahan sebesar, 1,20 persen, sandang sebesar 1,08 persen, kesehatan sebesar 0,41 persen, pendidikan rekreasi dan olah raga sebesar 0,33 persen, dan transportasi dan komunikasi sebesar 0,52 persen.

Kenaikan indeks harga pada kelompok biaya produksi dan penambahan barang modal sebesar 0,45 persen disebabkan karena kenaikan indeks harga pada bibit sebesar 2,65 persen, vaksin dan serum sebesar 0,14 persen, makanan ternak sebesar 0,95 persen, upah buruh sebesar 0,91 persen, pengeluaran lain sebesar 0,29 persen, serta barang modal sebesar 0,01 persen.

\section{Nilai Tukar Petani (NTP) Sub-sektor Perikanan}

Pada tahun 2018 terjadi kenaikan nilai tukar petani pada sub-sektor perikanan bila dibandingkan pada tahun 2017, yakni sebesar 0,39 persen. Hal ini terjadi karena baik indeks harga yang diterima petani (It) dan Indeks harga yang dibayar petani (Ib) sama-sama mengalai kenaikan. Indeks harga yang diterima petani (It) naik sebesar 1,14 persen sedangkan indeks harga yang dibayar petani (Ib) naik sebesar 0,65 persen.

\section{Tabel 7}

Nilai Tukar Petani, Indeks Harga Yang Diterima Petani, Indeks Harga Yang Dibayar Petani pada

Sub Sektor Perikanan

\begin{tabular}{|c|c|c|c|c|}
\hline \multirow{2}{*}{ No. } & \multirow{2}{*}{ Uraian } & \multicolumn{2}{|c|}{ NTP } & \multirow[t]{2}{*}{$\begin{array}{c}\text { Kenaikan } \\
(\%)\end{array}$} \\
\hline & & 2017 & 2018 & \\
\hline & Nilai Tukar Petani (NTP) & 112.48 & 112.87 & 0.39 \\
\hline \multirow[t]{2}{*}{1} & Indeks Harga Yang Diterima Petani (It) & 116.27 & 117.41 & 1.14 \\
\hline & Budidaya Perikanan & 116.27 & 117.41 & 1.14 \\
\hline 2 & Indeks Harga Yang Dibayar Petani (Ib) & 103.37 & 104.02 & 0.65 \\
\hline \multirow[t]{9}{*}{2.1} & Konsumsi Rumah Tangga & 104.23 & 105.19 & 0.96 \\
\hline & a. Bahan Makanan dan Minuman & 104.28 & 104.77 & 0.49 \\
\hline & Makanan Jadi & 113.84 & 114.16 & 0.32 \\
\hline & b. Non Makanan & 103.73 & 103.96 & 0.23 \\
\hline & Perumahan & 105.34 & 106.00 & 0.66 \\
\hline & Sandang & 105.51 & 105.64 & 0.13 \\
\hline & Kesehatan & 101.05 & 102.03 & 0.98 \\
\hline & Pendidikan, Rekreasi \& Olah raga & 102.43 & 102.49 & 0.06 \\
\hline & Transportasi \& Komunikasi & 101.14 & 101.52 & 0.38 \\
\hline \multirow[t]{7}{*}{2} & BPPBM & 103.35 & 103.43 & 0.08 \\
\hline & Bibit & 103.68 & 104.55 & 0.87 \\
\hline & Vaksin dan Serum & 99.56 & 100.14 & 0.58 \\
\hline & Makanan Ikan & 100.47 & 100.64 & 0.17 \\
\hline & Upah Buruh & 100.23 & 100.41 & 0.18 \\
\hline & Pengeluaran Lain & 100.66 & 100.70 & 0.04 \\
\hline & Barang Modal & 120.64 & 121.48 & 0.84 \\
\hline
\end{tabular}


Kenaikan indeks harga yang diterima petani (It) pada tahun 2018 dibanding dengan tahun 2017 sebesar 1,14 persen disebabkan karena indeks harga kelompok budidaya perikanan naik sebesar 1,14 persen.

Kenaikan indeks harga yang dibayar petani (Ib) sub-sektor perikanan pada tahun 2018 dibanding dengan tahun 2017 sebesar 0,65 persen, hal ini disebabkan kenaikan indeks harga pada kelompok konsumsi rumah tangga sebesar 0,96 persen dan kelompok Biaya Produksi dan Penambahan Barang Modal naik sebesar 0,08 persen.

Kenaikan indeks harga pada kelompok konsumsi rumah tangga sebesar 0,96 persen hal ini disebabkan karena kenaikan indeks harga pada bahan makanan dan minuman sebesar 0,49 persen, makanan jadi sebesar 0,32 persen, serta non makanan sebesar 0,23 persen.

Kenaikan indeks harga pada kelompok non makanan sebesar 0,23 persen disebabkan karena kenaikan indeks harga pada perumahan sebesar 0,66 persen, sandang sebesar 0,13 persen, kesehatan sebesar 0,98 persen, pendidikan rekresi dan olah raga sebesar 0,06 persen, serta transportasi dan komunikasi sebesar 0,38 persen.

Kenaikan indeks harga pada kelompok biaya produksi dan penambahan barang modal sebesar 0,08 persen disebabkan karena kenaikan indeks harga pada bibit sebesar 0,87 persen, vaksin dan serum sebesar 0,58 persen, makanan ikan sebesar 0,17 persen, upah buruh sebesar 0,18 persen, pengeluaran lain sebesar 0,04 persen dan barang modal sebesar 0,84 persen.

\section{Nilai Tukar Petani Tiap Kecamatan}

Nilai tukar petani di masing-masing kecamatan menunjukkan tingkat kesejahteraan petani. Apabila nilai tukar petani di suatu kecamatan diatas 100 maka petani tersebut mengalami surplus atau sejahtera. Adapun hasil perhitungan NTP di setiap kecamatan dirangkum sebagai berikut:

Tabel 8

Nilai Tukar Petani (NTP) Per Kecamatan di Kabupaten Jombang, Tahun 2017-2018 (2012=100)

\begin{tabular}{|l|c|c|}
\hline \multirow{2}{*}{ Kecamatan } & \multicolumn{2}{c|}{ NTP } \\
\cline { 2 - 3 } & $\mathbf{2 0 1 7}$ & $\mathbf{2 0 1 8}$ \\
\hline Bandar Kedung Mulyo & 117,23 & 123.17 \\
\hline Perak & 116,37 & 122.92 \\
\hline Gudo & 114,70 & 112.46 \\
\hline Diwek & 115,62 & 118.01 \\
\hline Ngoro & 116,28 & 111.66 \\
\hline Mojowarno & 114,89 & 116.13 \\
\hline Bareng & 114,41 & 117.07 \\
\hline Wonosalam & 112,86 & 111.43 \\
\hline Mojoagung & 114,54 & 117.84 \\
\hline Sumobito & 113,46 & 107.50 \\
\hline Jogoroto & 112,26 & 109.07 \\
\hline Peterongan & 113,99 & 108.19 \\
\hline Jombang & 114,73 & 116.30 \\
\hline Megaluh & 114,55 & 119.56 \\
\hline Tembelang & 111,58 & 105.04 \\
\hline Kesamben & 113,22 & 116.02 \\
\hline Kudu & 111,87 & 105.02 \\
\hline Ngusikan & 111,15 & 115.69 \\
\hline
\end{tabular}




\begin{tabular}{|l|c|c|}
\hline \multirow{2}{*}{ Kecamatan } & \multicolumn{2}{|c|}{ NTP } \\
\cline { 2 - 3 } & $\mathbf{2 0 1 7}$ & $\mathbf{2 0 1 8}$ \\
\hline Ploso & 112,16 & 112.68 \\
\hline Kabuh & 111,77 & 107.53 \\
\hline Plandaan & 113,73 & 114.37 \\
\hline Kabupaten Jombang & $\mathbf{1 1 3 , 9 2}$ & $\mathbf{1 1 3 . 9 9}$ \\
\hline \multicolumn{2}{|c|}{ Sumber data: Analisis Data Primer } \\
\hline
\end{tabular}

Secara keseluruhan nilai tukar petani di setiap kecamatan di kabupaten Jombang memiliki daya beli yang cukup tinggi atau dengan kata lain petani disetiap kecamatan masing-masing surplus atau sejahtera. Hal ini ditunjukkan dengan nilai tukar petani masih diatas 100. Namun demikian bila nilai tukar petani di setiap kecamatan disandingkan dengan nilai tukar petani disetiap kecamatan pada tahun 2017 memang hampir rata-rata menurun. Namun demikian menurunnya nilai tukar petani tersebut bukan berarti petani tidak mengalami surplus.

Indeks harga diterima petani (It) di semua kecamatan cukup tinggi dan hampir merata, nilai terbesar berada di Kecamatan Mojoagung, Sedangkan indeks harga dibayar oleh petani (Ib) terbesar di Kecamatan perak.

Berbagai faktor yang menyebabkan indeks harga diterima petani di kecamatan bervariasi sedemikian rupa, terutama adalah pertama, kemudahan petani dalam menjual hasil panennya. Semakin mudah menjual dan memiliki banyak pilihan pembeli, maka semakin tinggi harga yang diterima. Faktor kedua, adalah tingkat produksi tanaman pangan yang dihasilkan petani. Kecamatan yang memiliki hasil panen tinggi akan menyebabkan penawaran yang lebih besar dari pada tingkat permintaan pedagang setempat, sehingga peluang merosotnya harga komoditi lebih besar. Faktor ketiga adalah kemampuan petani dalam menahan dan menyimpan hasil panen sementara sambil menanti adanya kenaikan harga.

Sedangkan variasi nilai indeks harga yang dibayar petani (Ib), penyebabnya lebih rumit. Faktor utama adalah dekatnya lokasi petani dengan kota atau pasar yang cukup besar. Tingkat harga komoditi konsumsi dan biaya produksi cenderung lebih tinggi dari pada kecamatan yang jauh dari kota atau pasar besar. Faktor kedua, para petani di kecamatan yang relatif jauh dari kota relatif lebih hemat dalam pengeluaran rumah tangganya dari pada yang dekat dengan kota. Faktor ketiga adalah perbedaan pelaksanaan usahatani. Kecamatan yang memiliki jumlah buruh tani lebih banyak, cenderung mengeluarkan biaya produksi dan penambahan barang modal lebih sedikit dari pada kecamatan yang mengalami kekurangan atau defisit buruh tani. Faktor keempat, para petani yang memiliki penghasilan tambahan dari luar usahatani cenderung lebih konsumtif dan lebih banyak mengalokasikan sarana produksi. Sehingga nilai Ib lebih tinggi dari rata-rata kecamatan. Misalnya, para petani yang memiliki sumber penghasilan tambahan dari sapi perah atau berdagang akan cenderung membeli pupuk dan pestisida lebih banyak, dari pada yang tidak memiliki sumber penghasilan tunai.

\section{KESIMPULAN DAN REKOMENDASI Kesimpulan}

\section{Nilai Tukar Petani (NTP) Kabupaten Jombang}

Nilai tukar petani (NTP) Kabupaten Jombang pada tahun 2018 tercapai sebesar 113,99, meningkat $0,07 \%$ dibandingkan NTP pada tahun 2017, yaitu 113,92 . Hal ini 
menunjukkan bahwa tingkat kesejahteraan petani di Kabupaten Jombang pada tahun 2018 meningkat atau lebih baik dari pada tahun 2017.

Kenaikan nilai tukar petani tersebut disebabkan karena indeks harga yang diterima petani (It) mengalami kenaikan sebesar 2,00 persen dan indeks harga yang dibayar petani (Ib) juga mengalami kenaikan sebesar 1,70 persen.

\section{Nilai Tukar Petani (NTP) Kecamatan}

Nilai tukar petani (NTP) di semua kecamatan pada tahun 2018 juga cukup baik artinya NTP nya diatas 100, namun bila disandingkan dengan NTP masing-masing kecamatan pada tahun 2017 hampir rata-rata mengalami penurunan. Namun demikian petani di setiap kecamatan tetap surplus.

\section{Rekomendasi}

Berdasarkan hasil kajian ini, dapat disusun beberapa rekomendasi yang terkait dengan Nilai Tukar Petani di Kabupaten Jombang, meliputi:

1. Menetapkan kegiatan penyusunan NTP Kabupaten Jombang sebagai kegiatan yang berkelanjutan dalam kerangka penilaian dan pengembangan program-program pertanian.

2. Meningkatkan kualitas dan transparansi data penunjang perhitungan NTP Kabupaten Jombang yang mencakup data bulanan, semesteran dan tahunan tentang produksi usahatani, harga komoditi di tingkat petani, dan harga barang dan jasa yang dibayar oleh rumah tangga petani.

3. Bagi pemerintah daerah sebagai pengambil kebijakan diharapkan untuk meningkatkan perhatian pada upaya-upaya peningkatan kesejahteraan petani, melalui beberapa program prioritas sebagai berikut:

a. Peningkatan kualitas ekologi pertanian dengan target meningkatkan kesuburan lahan pertanian, ketersediaan air pertanian yang berkualitas, dan penerapan prinsip pertanian berkelanjutan atau pertanian organik.

b. Peningkatan produktivitas lahan pertanian yang ada dari sisi ekonomi, dengan melakukan penganekaragaman tanaman tumpangsari atau pasca musim tanam padi, seperti penanaman tanaman hortikultura semusim atau tanaman palawija yang mudah dipasarkan.

c. Meningkatkan pemerataan penerapan mekanisasi pertanian di semua kecamatan dengan mempertimbangkan kondisi dan kebutuhan di masing-masing desa dan mempertimbangkan kearifan lokal yang dimiliki oleh kelompok tani.

\section{DAFTAR PUSTAKA}

-----------, 2016. Jombang Dalam Angka, 2016. Badan Pusat Statistik. Kabupaten Jombang.

-, 2016. Survei Pertanian Padi dan Palawija Provinsi Jawa Timur, 2016. Badan Pusat Statistik. Provinsi Jawa Timur.

-, 2014. Outlook Komoditi Tebu. Pusat Data dan Sistem Informasi Pertanian. Sekretariat Jenderal Kementerian Pertanian. Jakarta. 
2014. Hasil Survei Sosial Ekonomi Nasional Tahun 2014 Provinsi Jawa Timur. BPS Provinsi Jawa Timur. Surabaya.

-, 2013. Analisis Nilai Tukar Petani (NTP)SebagaiBahan Penyusunan RPJMN Tahun 2016-2019, KerjasamaKementerian Perencanaan Pembangunan Nasional/Bappenas dan Japan International Cooperation Agency(Jica), Direktorat Pangan dan Pertanian Bappenas. Jakarta.

2013. Analisis Sosial Ekonomi Petani Jawa Timur. Analisis Hasil Survei Pendapatan Petani. Sensus Pertanian 2013. BPS Provinsi Jawa Timur. Surabaya.

-----------, 2013. Analisis Ruma Tangga Usaha Tanaman Pangan Jawa Timur. Hasil Sensus Pertanian 2013. BPS Provinsi Jawa Timur. Surabaya.

Ali Rosidi, ST. 2007. Nilai Tukar Petani (NTP) Sebagai Indikator Tingkat Kesejahteraan Petani. Materi Pertemuan Dan Diskusi Terbatas Mengenai "Nilai Tukar Petani (NTP)" Pusat Analisis Sosial Ekonomi Dan Kebijakan Pertanian Departemen Pertanian, Bogor.

Bambang Avip P.M., 2016. Populasi dan Sampel. Bahan Kuliah Fakultas MIPA. Universitas Pendidikan Indonesia. Bandung.

Rachmat, M. 2013. Nilai Tukar Petani: Konsep, Pengukuran Dan Relevansinya Sebagai Indikator Kesejahteraan Petani. Forum Penelitian Agro Ekonomi, Volume 31 No. 2, Desember 2013.Pusat Sosial Ekonomi dan Kebijakan Pertanian. Bogor.

Rachmat, M., Supriyati, Deri Hidayat dan Jefferson Situmorang. 2000. Perumusan Kebijaksanaan Nilai Tukar Petani dan Komoditi Pertanian. LaporanHasil Penelitian. Pusat Penelitian Sosial Ekonomi Pertanian. Departemen Pertanian. Bogor.Rachmat, Muchjidin. 2000. Analisa Nilai Tukar Petani Indonesia. Disertasi. Institut Pertanian Bogor. 